\title{
Pemanasan Global Sebagai Pertanda Akhir Zaman
}

\author{
Ari Sugiarto \\ Email: sugiartoari13@gmail.com
}

\begin{abstract}
Abstrak
Pemanasan global telah menjadi salah satu topik permasalahan terbesar yang dihadapi pada abad ke-21 ini. Berbagai masalah yang akan muncul dari dampak pemanasan global tentunya akan mengancam kehidupan di Bumi. Dampak tersebut terlihat berkaitan dan dapat memunculkan dampak negatif lainnya. Permasalahan tersebut tentunya sulit untuk diatasi atau dicegah. Namun jika, permasalahan tersebut benar akan terjadi tentunya kehidupan di Bumi telah mendekati akhir. Mitigasi dampak pemanasan global serta beradaptasi untuk mempersiapkan diri dalam menghadapi dampak yang ditimbulkan tersebut adalah pilihan terbaik yang dapat dilakukan.
\end{abstract}

Kata kunci: Pemanasan global, Dampak pemanasan global

\section{Pemanasan Global}

Pemanasan global telah menjadi salah satu permasalahan terbesar yang dihadapi pada abad ke-21 ini. Pemanasan global merupakan peningkatan suhu udara rata-rata permukaan Bumi yang disebabkan oleh panas yang diterima dari Matahari terperangkap oleh gas-gas rumah kaca. Menurut Kristanto (2004), uap air, $\mathrm{CO}_{2}, \mathrm{CH}_{4}$, Ozon, $\mathrm{N}_{2} \mathrm{O}$ dan Klorofluorokarbon (CFC) merupakan gas-gas rumah kaca di atmosfer. Adanya gas-gas rumah kaca (uap air dan $\mathrm{CO}_{2}$ ) diatmosfer akan meningkat sebesar suhu udara sebesar $33{ }^{\circ} \mathrm{C}$ dari kondisi suhu tanpa efek rumah kaca \pm $18{ }^{\circ} \mathrm{C}$, yang tentunya membantu terbentuknya kehidupan di Bumi. Namun karena adanya gas-gas rumah kaca lain seperti $\mathrm{CO}_{2}, \mathrm{CH}_{4}$, $\mathrm{N}_{2} \mathrm{O}$ dan Klorofluorokarbon (CFC) akan menyebabkan panas samakin sulit dilepaskan keluar angkasa, hal ini dikarenakan absorbsi panas oleh uap air yang berada pada panjang gelobang $4.10^{3}$ sampai $7.10^{3} \mathrm{~nm}$ dan $\mathrm{CO}_{2}$ pada $13.10^{3}$ sampai $17.10^{3} \mathrm{~nm}$. Antara panjang gelombang $7.10^{3}$ dan $13.10^{3}$ terdapat jendela yang dapat dilalui oleh panas untuk lepas ke luar angkasa, namun adanya gas-gas rumah kaca yang memiliki spektrum absorbsi antara $7.10^{3}$ dan $13.10^{3}$ maka akan semakin sedikit panas yang dapat dilepas ke luar angkasa.

Data suhu udara sejak periode pra industri menunjukkan telah terjadinya peningkatan suhu udara sebesar $1{ }^{\circ} \mathrm{C}$ (World Development Report, 2010) dan diperkirakan dalam waktu beberapa dekade kedepan peningkatan suhu udara sebesar $1-3{ }^{\circ} \mathrm{C}$ (Bhattacharjee, 2010). Data peningkatan suhu udara di wilayah belahan Bumi menunjukkan peningkatan suhu udara bervariasi, seperti di Sumatera Selatan (Indonesia) dalam kurun waktu 1977-2017 peningkatan suhu udara minimum sebesar $1,5^{\circ} \mathrm{C}$, peningkatan suhu udara rata-rata harian sebesar $1,3{ }^{\circ} \mathrm{C}$, dan peningkatan suhu udara maksimum sebesar 1,2 ${ }^{\circ} \mathrm{C}$ (Sugiarto et al., 2018). Di Jepang terjadi peningkatan suhu udara sebesar 1,15 ${ }^{\circ} \mathrm{C}$ dalam kurun waktu 100 tahun (Ministry of Environment Japan, 2012), peningkatan suhu udara di Australia berkisar $1{ }^{\circ} \mathrm{C}$ sejak tahun 1910 (Australian Climate Change Science Programme, 2016).

\section{Dampak Pemanasan Global}

1. Dampak pemanasan global terhadap sifatsifat atom 
Dampak pemanasan global terhadap sifatsifat atom yaitu menyebabkan terjadinya perubahan dalam sifat-sifat atom dari unsurunsur seperti gerak, valensi, magnet, listrik, konduksi, struktur elektronik, struktur kristal, elektropositivitas dan elektronegativitas dan lain-lain magnet Bumi dan gravitasi (Bhattacharjee, 2010).

2. Dampak pemanasan global terhadap lingkungan

Dampak pemanasan global terhadap lingkungan dapat menyebabkan kenaikan permukaan air laut di seluruh dunia, mencairnya es di kutub, keasaman air laut meningkat yang membuat pemutihan terumbu karang (Chaeran, 2015), hilangnya gletser (Wang dan Chameides, 2005), meningkatnya intensitas fenomena cuaca yang ekstrim (Parwito, 2016), munculnya gejala alam El Nino/Enso, banjir dan kekeringan, kebakaran hutan, munculnya daerah kritis baru (Suwedi, 2005), terjadinya gelombang panas (Venkataramanan and Smitha, 2011), perubahan jumlah dan model curah hujan (Özdemđr dan Altindağ, 2009), serta mempengaruhi magnet Bumi dan gravitasi (Bhattacharjee, 2010).

3. Dampak pemanasan global terhadap pertanian

Dampak pemanasan global terhadap pertanian berdampak pada produktivitas hasil pertanian (Bank of Grecee, 2011), invasi serangga hama pertanian (California Environmental Protection Agency, 2018), perubahan respon tanaman terhadap suhu dan $\mathrm{CO}_{2}$ (Hatfield et al., 2008).

4. Dampak pemanasan global terhadap mahluk hidup

Dampak pemanasan global terhadap mahluk hidup seperti peningkatan kamatian dini pada manusia (Bank of Grecee, 2011), kematian manusia yang disebabkan oleh panas, penurunan kedatangan burung migrasi, penurunan populasi amphibi, perubahan waktu pembuahan dan kematangan biji, pergeseran rentang spesies (California Environmental Protection Agency, 2018), ancaman kesehatan manusia (Climate Change and Sustainability Committee, 2015), meningkatnya resiko penyakit yang ditularkan nyamuk, kepunahan spesies (Moore, 1998), meningkatnya laju transpirasi tanaman (Sugiarto, 2018), kepunahan terumbu karang (Wang dan Chameides, 2005).

\section{Kaitan Pemanasan Global sebagai Pertanda Akhir}

Pemanasan global yang menyebabkan permasalahan yang sangat besar bagi lingkungan dan mahluk hidup. Ancaman kekeringan, banjir, naiknya permukaan air laut akbiat dari mencainya es di kutub yang dapat menenggelamkan daratan, peningkatan suhu air laut, perubahan curah hujan, mempercepat penguapan air dan transpirasi tanaman, serta kepunahan spesies merupakan dampak pemanasan global yang saling berkaitan dan tentunya dapat menimbulkan dampak negatif lainnya. Terjadinya peningkatan penguapan air tentunya dapat mempercepat terjadinya kekeringan pada suatu wilayah, ini juga dapat bertambah parah dengan diikuti curah hujan yang sedikit. Jumlah air tanah yang sangat sedikit pada wilayah yang kekeringan tentunya sangat berpengaruh pada mahluk hidup terutama tumbuhan.

Tumbuhan membutuhkan air untuk fotosintesis dan mendinginkan tubuh dari lingkungan yang panas dengan melakukan transpirasi. Semakin tinggi suhu lingkungan sekitar tanaman tentunya akan menyebabkan terjadinya peningkatan laju transpirasi yang artinya membuhkan air lebih banyak untuk di uapkan sebagian besar melalui daun. Jumlah air tanah sangat sedikit dan suhu lingkungan sekitar tanaman yang tinggi, tumbuhan dapat beradaptasi dengan menggugurkan daunnya untuk mengurangi penguapan air yang terjadi dari proses transpirasi. Namun disinilah dampak negatif lainnya akan muncul, tumbuhan yang menggurkan daunya sebagai bentuk adaptasi terhadap suhu lingkungan sekitar yang panas dan cekaman kekurangan air akan mengalami masalah pada fotosintesisnya, kerena fotosintesis terjadi 
pada daun. Dalam fotosintesis juga diperlukan air, namun yang tidak kalah penting juga dibutuhkan karbon dioksida $\left(\mathrm{CO}_{2}\right)$. Karbon dioksida merupakan salah satu gas rumah kaca penyebab terjadinya pemanasan global.Berkurangnya kemampuan fotosintesis tanaman akan menyebabkan berkurangnya penyerapan karbon dioksida diatmosfer yang artinya jumlah gas rumah kaca diatmosfer akan terus bertambah, hal ini dikarenakan produksi karbon dioksida yang tetap atau bahkan terus bertambah dibanding serapan karbon dioksida oleh tanaman. Dampak negatif yang tak kalah penting yaitu dari fotosintesis akan dihasilkan oksigen $\left(\mathrm{O}_{2}\right)$ yang sangat dibutuhkan mahluk hidup untuk bernapas, seperti pada manusia dan hewan.

Air jelas merupakan kebutuhan vital untuk mendukung kehidupan. Manusia membutuhkan air untuk berbagai proses fisiologis di dalam tubuh dan begitu juga mahluk hidup lainnya yang juga sangat membutuhkan air. Kekeringan akan berakibat fatal bagi kehidupan di Bumi ini. Bagi manusia, salah satu dampak kekeringan akan mempengaruhi sektor pertanian. Ancaman gagal panen menjadi hal yang sangat nyata untuk dihadapi. Selain itu, peningkatan potensi serangan hama pada sektor pertanian sangat mungkin terjadi. Terjadinya gagal panen akan menyebabkan terjadinya kesenjangan pangan yang menimbulkan kasus kelaparan masal pada wilayah yang kekeringan. Selain itu juga dari dampak peningkatan suhu yang terjadi akan meyebabkan akan terjadinya perubahan waktu pembuahan dan kematangan biji pada tanaman perkebunan. Meningkatnya suhu air laut juga akan menimbulkan dampak yang besar terhadap kelangsungan kehidupan di kawasan perairan, kepunahan terumbu karang. Selain itu, beberapa ikan memerlukan suhu tertentu untuk dapat hidup pada suatu perairan.

Beberapa uraian mengenai rentetan dampak pemanasan global diatas memberikan gambaran tentang berbagai masalah terbesar yang akan terjadi nanti. Permasalahan tersebut tentunya sulit untuk diatasi atau dicegah. Namun jika, permasalahan tersebut benar akan terjadi tentunya kehidupan di Bumi telah mendekati akhir. Dalam sudut pandang Islam, kekeringan memang pertanda akhir zaman. Air memang sumber kehidupan seperti yang tertulis dalam Al-Quran surat Qaf ayat 9 dan 11 yaitu "Dan dari langit kami turunkan air yang memberi berkah, lalu kami tumbuhkan dengan (air) itu pepohonan yang rindang dan biji-bijian yang dapat dipanen....dan kami hidupkan dengan (air) itu negeri yang mati (tandus)". Ini juga dijelaskan dalam surat Az-Zumar ayat 21 "...bahwa Allah menurunkan air dari langit, lalu diaturnya menjadi sumber-sumber air di bumi, kemudian dengan air itu ditumbuhkanNya tanam-tanaman yang bermacam-macam warnanya...". Tanda-tanda kekeringan pada danau Tiberias dan sungai Eufrat merupakan pertanda akhir zaman. Selain itu, berhentinya berbuah kebun kurma Baisan juga menjadi pertanda akhir zaman. Hal terbaik yang dapat kita lakukan adalah melakukan mitigasi dampak pemanasan global serta beradaptasi untuk mempersiapkan diri dalam menghadapi dampak yang ditimbulkan tersebut.

\section{Daftar Pustaka}

Australian Climate Change Science Programme. 2016. Australia's Changing Climate. Asutralian Government, Department the Environment and Energy, Bureau of Metereology. Hal 2-9.

Bank of Grecee. 2011. The Environmental, Economic and Social Impacts of Climate Change in Greece. Economic Research Department - Secretariat, E. Venizelos Avenue GR-102 50 Athens. Hal 187-268. 
Bhattacharjee, P. K. 2010. Global Warming Impact on the Earth. International Journal of Environmental Science and Development. 1(3): 219-220.

California Environmental Protection Agency. 2018. Indicators of Climate Change in California. Hal 171-318.

Chaeran, M. 2015. Global Warming. Jurnal Sain dan Teknologi Maritim. 13(2): 76-85.

Climate Change and Sustainability Committee. 2015. Climate Change and Resource SustainabilityAn Overview for Actuaries. Canadian Institute of Actuaris. Hal 16.

Hatfield, J., K. Boote, P. Fay, L. Hahn, C. Izaurralde, B.A. Kimball, T. Mader, J. Morgan, D. Ort, W. Polley, A. Thomson, and D. Wolfe. 2008. Agriculture. in: The effects of climate change on agriculture, land resources, water resources, and biodiversity in the United States. A Report by the U.S. Washington, DC, USA: Climate Change Science Program and the Subcommittee on Global Change Research. Hal 362.

Kristanto, P. 2004. Ekologi Industri. Yogyakarta: Andi.

Ministry of Environment Japan, Consolidated Report on Observations. 2012. Projections and Impact Assessments of Climate Change: Climate Change and Its Impacts in Japan. https://www.env.go.jp/en/earth/cc/impacts_FY2012.pdf. Diakses pada 13 Maret 2019. Hal 2.

Moore, T.G. 1998. Climate of Fear: Why we shouldn't worry about global warming, Washington, D.C: 1000 Massachusetts Ave. Hal 75-78.

Özdemđr, E and Altindağ, A. 2009. The Impact of Global Warming on Aquatic Life. Ankara University Journal of Environmental Sciences, 1(1): 7-15

Parwito, U. 2016. Pemanasan Global-Protokol Kyoto dan Penerapan Kaidah Arsitektur Ekologis. Jurnal Ilmiah KORPRI Kopertis Wilayah IV. 1(1): 1-11.

Q.S. Az-Zumar. 39: 21.

Q.S. Qaf. 50: 9 dan 11.

Sugiarto, A. 2018. Pengaruh Peningkatan Suhu Udara Terhadap Laju Transpirasi Bibit Lansium domesticum Corr. Skripsi. Jurusan Biologi, Fakultas Matematika dan Ilmu Pengetahua Alam, Universitas Sriwijaya. Hal 16-17. DOI: $10.13140 /$ RG.2.2.25556.86405/1.

Sugiarto, A., Hanifa, M., and Sarno. 2018. Pemanasan Global di Sumatera Selatan dan Peningkatan Suhu Udara yang Terjadi: Pemodelan Pengaruhnya Terhadap Transpirasi Lansium domesticum Corr. Inderalaya: Jurusan Biologi, Fakultas Matematika dan Ilmu Pengetahuan Alam, Universitas Sriwijaya. Hal 26-27. DOI: $10.31227 /$ osf.io/st4eh.

Suwedi, N. 2005. Upaya Pencegahan and Penanggulangan Dampak Pemanasan Global. Jurnal Teknologi Lingkungan. 6(2): 397-401. 
Venkataramanan, M and Smitha. 2011. Causes and effects of global warming. Indian Journal of Science and Technology. 4(3): 226-229.

Wang, J and Chameides, B. 2005. Global Warming's Increasingly Visible Impacts. Environmental Defence. Hal 19-20.

World Development Report. 2010. Laporan Pembangunan Dunia 2010; Pembangunan dan Perubahan Iklim. Diterjemahkan oleh. Sungkono, C. Jakarta: Salemba Empat. 